\title{
FAKTOR YANG BERHUBUNGAN DENGAN KEJADIAN POST PARTUM BLUES PADA IBU NIFAS DI RUANG NURI RUMAH SAKIT BHAYANGKARA MAKASSAR
}

Factors related to post partum blues occurrence in Nuri Ward Bhayangkara Hospital Makassar

Ernawati ${ }^{1}$

1STIKES Nani Hasanuddin Makassar

Corresponding email: ernawati@stikesnh.ac.id dan 085299947711

\begin{abstract}
The purpose of this study was to determine the factors associated with the occurrence of post partum blues in postpartum ward (Nuri ward) at Bhayangkara Hospital Makassar. This study was quantitative analytic research with cross-sectional approach. This research was conducted in Nuri ward of Bhayangkara Hospital in Makassar during August 2019. The population of this study was postpartum mothers who were cared for during August 2019. Subjects involved in this study were 54 postpartum mothers obtained through incidental sampling techniques. The independent variables include the type of labor, parity, and family support with the dependent variable namely the post partum blues occurrence. Data were processed and analyzed using SPSS for Windows with Chi-square statistical test with alternative Fisher exact test. The results showed that of 54 postpartum mothers participating in this study, 14 mothers (25.93\%) showed the possibility of experiencing post partum blues. There was a significant relationship between the type of labor $(p=0.041)$ and maternal parity $(p=0.003)$ with the incidence of post partum blues in postpartum mothers cared in the hospital Bhayangkara Makassar. Husband and family support is very important in preventing postpartum blues in postpartum mothers.
\end{abstract}

Keywords : type of labor, parity, family support, post partum blues

\section{ABSTRAK}

Tujuan penelitian ini untuk mengetahui faktor yang berhubungan dengan terjadinya post partum blues pada ibu nifas di Rumah Sakit Bhayangkara Makassar. Jenis penelitian kuantitatif analitik dengan pendekatan cross-sectional. Penelitian ini dilaksanakan di Ruang Nuri RS. Bhayangkara Makassar selama Bulan Agustus Tahun 2019. Populasi penelitian ini adalah ibu nifas yang di rawat selama pelaksanaan penelitian. Subject yang terlibat dalam penelitian ini sebanyak 54 ibu nifas yang diperoleh melalui teknik insidental sampling. Variabel independen meliputi jenis persalinan, paritas, dan dukungan keluarga dengan variabel dependennya yakni kejadian post partum blues. Data diolah dan dianalisis menggunakan SPSS for Windows dengan Uji statistic Chi-square dengan uji alternatif Fisher exact test. Hasil penelitian menunjukkan dari 54 ibu nifas yang berpartisipasi dalam penelitian ini, 14 ibu (25,93\%) menunjukkan kondisi kemungkinan mengalami post partum blues. Ada hubungan yang signifikan antara jenis persalinan $(p=0,041)$ dan paritas ibu $(p=0,003)$ dengan kejadian post partum blues pada ibu bersalin di RS. Bhayangkara Makassar. Dukungan suami dan keluarga sangat penting dalam mencegah terjadinya postpartum blues pada ibu nifas.

Kata kunci : jenis persalinan, paritas, dukungan keluarga, post partum blues

\section{PENDAHULUAN}

Depresi setelah melahirkan ini adalah gangguan psikologis yang dalam istilah kedokteran disebut post partum blues. Postpartum blues merupakan masa transisi mood setelah melahirkan yang sering terjadi pada $50-70 \%$ wanita pasca melahirkan (Sujiyatini, 2010).

Penyebab postpartum blues tidak diketahui secara pasti namun salah satunya adalah riwayat kehamilan dan jenis persalinan. Persalinan dengan sectio caesarea mempunyai hubungan yang signifikan dengan kemungkinan terjadinya postpartum blues $25 \%$ dari persalinan caesar dan $8 \%$ dari persalinan normal (Freudenthal, Corst \& Kaminski, 1999).
Mereka yang melahirkan dengan operasi caesar cenderung menderita depresi jika dibandingkan mereka yang melahirkan secara normal. Para peneliti beranggapan ini di sebabkan oleh perasaan gagal yang timbul karena tidak dapat melahirkan secara normal. Kemungkinan depresi juga timbul karena proses pemulihan pasca operasi caesar akan memakan waktu lebih lama.

Angka kejadian post partum blues di Asia cukup tinggi dan bervariasi antara 26-85\%, sedangkan di Indonesia angka kejadian post partum blues antara $50-70 \%$ dari wanita pasca persalinan (Ratna 2009). Dari beberapa penelitian dijelaskan sebanyak $50 \%$ ibu setelah melahirkan mengalami 
depresi setelah melahirkan dan hampir $80 \%$ ibu baru melahirkan mengalami perasaan sedih setelah melahirkan atau sering disebut post partum blues (Kasdu, 2003). Post partum blues atau sering juga disebut maternity blues atau baby blues dimengerti sebagai suatu sindroma gangguan afek ringan yang sering tampak dalam minggu pertama setelah persalinan dan memuncak pada hari ke tiga sampai kelima dan menyerang dalam rentang waktu 14 hari terhitung setelah persalinan (Arfian, 2012).

Adapun tanda dan gejalanya seperti: reaksi depresi/sedih/disforia, menangis, mudah tersinggung (iritabilitas), cemas, labilitas perasaan, cenderung menyalahkan diri sendiri, gangguan tidur dan gangguan nafsu makan. Gejala ini mulai muncul setelah persalinan dan pada umumnya akan menghilang dalam waktu antara beberapa jam sampai beberapa hari. Namun, pada beberapa minggu atau bulan kemudian dapat berkembang menjadi keadaan yang lebih berat (Murtiningsih, 2012).

Kondisi lain yang mendukung terjadinya postpartum blues adalah respon dari ketergantungan karena kelemahan fisik, harga diri rendah dan kelelahan, jauh dari keluarga, ketidaknyamanan fisik dan ketegangan dengan peran baru terutama pada perempuan yang tidak memiliki dukungan dari pasangan (Bobak, 2005). Riawayat kehamilan dan persalinan dengan komplikasi juga dapat menjadi faktor pendukung terjadinya postpartum blues. Salah satu kasus persalinan dengan komplikasi adalah persalinan lama. Persalinan lama dengan seksio saesarea mempunyai hubungan yang signifikan dengan kemungkinan terjadinya postpartum blues (Ratna, 2009).

Post partum blues dikategorikan sebagai sindroma gangguan mental ringan, oleh sebab itu sering tidak dipedulikan dan diabaikan sehingga tidak terdiagnosa dan tidak dilakukan asuhan sebagaimana mestinya. Padahal apabila postpartum blues tidak kunjung reda keadaan ini akan berkembang menjadi depresi postpartum. Perempuan dapat sering merasakan kesedihan, sulit berkonsentrasi, perasaan bersalah dan tak berharga. Bentuk depresi postpartum yang tidak tertangani dengan baik akan mengakibatkan postpartum psikosis yang mengakibatkan penderita dapat mengalami perubahan mood secara drastis.

\section{METODE}

\section{Desain, tempat dan waktu}

Jenis penelitian kuantitatif analitik dengan pendekatan cross-sectional. Penelitian akan dilaksanakan di Ruangan Nuri (post natal care) Rumah Sakit Bhayangkara Makassar pada bulan Agustus 2019.

\section{Jumlah dan cara pengambilan subjek}

Populasi dalam penelitian ini adalah ibu nifas di ruangan Nuri RS. Bhayangkara Makassar. Sampel dalam penelitian ini sebanyak 54 ibu nifas yang memenuhi kriteria inklusi dan eksklusi diperoleh melalui teknik insidentil sampling yakni ibu nifas yang dirawat di Bulan Agustus 2019 yang ditemui oleh peneliti dan bersedia berpartisipasi dalam penelitian ini. Cara pengumpulan data menggunakan kuesioner yang terdiri dari pertanyaan-pertanyaan dibuat sendiri oleh peneliti berdasarkan literatur yang digunakan. Penelitian ini mengukur tentang faktor yang berhubungan dengan Kejadian Postpartum Blues yang terdiri dari tiga variabel yaitu Paritas, jenis persalinan, dan dukungan keluarga.

\section{HASIL}

Karakteristik subjek penelitian terlihat bahwa dominan ibu nifas berada pada kelompok umur 20-29 tahun (66,7\%), $<20$ tahun $(9,3 \%), 30-39$ tahun $(22,2 \%)$, dan ada 1 ibu nifas $(1,9 \%)$ yang melahirkan pada rentang umur berisiko $\geq 40$ tahun. Tingkat pendidikan partisipan dominan adalah tamatan SMA $(59,3 \%)$, dan ada 1 partisipan yang tidak pernah mengikuti pendidikan formal $(1,9 \%)$, SD $(5,6 \%)$, SMP $(20,4 \%)$, D3 $(1,9 \%)$. Pekerjaan partisipan dominan adalah sebagai lbu Rumah Tangga $(79,6 \%)$ dan ada 3 partisipan yang bekerja sebagai pegawai negeri sipil $(5,6 \%)$, dan Wiraswasta $(14,8 \%)$.

$$
\text { Distribusi Partisipan (lbu Nifas) }
$$

berdasarkan Status Obstetri di Ruang Nuri RS. Bhayangkara Makassar terlihat bahwa dominan partisipan dalam penelitian ini ada Ibu Primipara $(51,9 \%)$ dan sisanya adalah multipara $(48,1 \%)$. Dalam hal riwayat abortus, diperoleh bahwa terdapat $20,4 \%$ partisipan menyatakan pernah mengalami abortus dan lainnya $(79,6 \%)$ tidak ada riwayat. Dalam hal perencanaan kehamilan, terdapat 25,9\% partisipan menyatakan bahwa persalinan saat ini adalah kehamilan yang tidak direncanakan. Dari 54 ibu nifas yang berpartisipasi dalam penelitian, 83,3\% merupakan persalinan normal dan sisanya $16,7 \%$ melalui sectio caesaria. Selain itu 37 ibu nifas $(68,5 \%)$ menyatakan memiliki riwayat gangguan psikologis sebelum dan saat hamil dan melahirkan.

Dalam hal riwayat pre menstrual syndrome, terdapat $87,0 \%$ partisipan pernah mengalami Riwayat Pre Menstrual Syndrome. Seluruh responden mendapat dukungan sosial dari suami atau keluarga. Hasil penelitian ini menemukan bahwa dari 54 ibu nifas, didapatkan $25,9 \%$ responden kemungkinan mengalami Post Partum Blues.

Hasil analisis bivariat dapat dilihat pada Tabel 1 dan 2 berikut: 
Tabel 1. Hubungan antara Jenis persalinan dengan kejadian Post Partum Blues di Ruang Nuri RS. Bhayangkara Makassar

\begin{tabular}{|c|c|c|c|c|c|c|}
\hline \multirow{3}{*}{ Jenis Persalinan } & \multicolumn{4}{|c|}{ Kejadian Post Partum Blues } & \multicolumn{2}{c|}{ Total } \\
\cline { 2 - 5 } & \multicolumn{2}{|c|}{ Tidak mengalami } & \multicolumn{2}{|c|}{ Kemungkinan mengalami } & $\mathrm{n}$ & $\%$ \\
\cline { 2 - 5 } & $\mathrm{n}$ & $\%$ & $\mathrm{n}$ & $\%$ & 45 & 100,0 \\
\hline Persalinan normal & 36 & 80,0 & 9 & 20,0 & 9 & 100,0 \\
\hline Sectio caesaria & 4 & 44,4 & 5 & 55,6 & 9 \\
\hline \multicolumn{7}{|c|}{ Nilai $\mathrm{p}=0,041$ (Fisher exact test) } \\
\hline
\end{tabular}

Tabel 1 menunjukkan bahwa dari 45 partisipan yang melahirkan melalui pervaginam (persalinan normal), 9 partisipan $(20,0 \%)$ kemungkinan mengalami kejadian Post Partum Blues, sedangkan dari 9 partisipan yang bersalin melalui metode operasi Sectio caesaria, 5 partisipan $(55,6 \%)$ kemungkinan mengalami kejadian Post
Partum Blues. Hasil uji statistik Fisher exact test diperoleh nilai $p=0,041$ yang menyatakan bahwa secara statistik terdapat hubungan yang signifikan antara Jenis Persalinan dengan kejadian Post Partum Blues pada Ibu bersalin di Ruang Nuri RS. Bhayangkara Makassar.

Tabel 2. Hubungan antara paritas dengan kejadian Post Partum Blues di Ruang Nuri RS. Bhayangkara Makassar

\begin{tabular}{|l|c|c|c|c|c|c|}
\hline \multirow{3}{*}{ Paritas } & \multicolumn{3}{|c|}{ Kejadian Post Partum Blues } & \multicolumn{2}{c|}{ Total } \\
\cline { 2 - 5 } & \multicolumn{2}{|c|}{ Tidak mengalami } & Kemungkinan mengalami & \multirow{2}{*}{$\mathrm{n}$} & \multirow{2}{*}{$\%$} \\
\cline { 2 - 6 } & $\mathrm{n}$ & $\%$ & $\mathrm{n}$ & $\%$ & 28 & 100,0 \\
\hline Primipara & 26 & 92,9 & 2 & 7,1 & 26 & 100,0 \\
\hline Multipara & 14 & 53,8 & 12 & 46,2 & 26 \\
\hline \multicolumn{3}{|c|}{ Nilai $\mathrm{p}=0,003$ (Pearson Chi-Square Continuity correction) } \\
\hline
\end{tabular}

Tabel 2 menunjukkan bahwa dari 28 partisipan dengan status paritas primipara, 7,1\% kemungkinan mengalami kejadian Post Partum Blues, sedangkan dari 26 partisipan dengan status paritas multipara, $46,2 \%$ kemungkinan mengalami kejadian Post Partum Blues. Hasil uji statistik Pearson Chi-Square dengan Continuity correction diperoleh nilai $p=0,003$ yang menyatakan bahwa secara statistik terdapat hubungan yang signifikan antara paritas dengan kejadian Post Partum Blues pada Ibu bersalin di Ruang Nuri RS. Bhayangkara Makassar. Dari 54 partisipan seluruhnya mendapat dukungan sosial dari suami dan keluarga. Dari jumlah tersebut, 25,9\% diantaranya kemungkingan mengalami kejadian post partum blues.

\section{PEMBAHASAN}

\section{Hubungan jenis persalinan dengan kejadian Post Partum Blues}

Hasil penelitian ini menunjukkan bahwa jenis persalinan memiliki hubungan dengan kejadian Post Partum Blues pada ibu nifas. Ibu yang bersalin melalui metode sectio caesaria memiliki kemungkinan mengalami Post Partum Blues dibandingkan dengan ibu yang melahirkan melalui pervaginam (persalinan normal). Kejadian stres tidak dapat dihindarkan pada ibu yang melahirkan dengan sectio caesaria. lbu yang bersalin dengan metode sectio caesaria memiliki risiko meninggal $3: 1$ dibandingkan dengan yang melahirkan pervaginam. Perasaan tertekan dilaporkan oleh $25 \%$ ibu karena penetapan prosedur tersebut terhadap persalinannya oleh tenaga kesehatan (Menacker dan Dentzer, 2006). Hasil penelitian Kurniasari (2015) menemukan $17,1 \%$ ibu yang menjalani persalinan dengan metode sectio caesaria mengalami kejadian post partum blues.

Hasil penelitian ini sejalan dengan penelitian yang dilaksanakan oleh Fatmah, dkk (2012) yang menyatakan hubungan signifikan antara jenis persalinan dengan depresi post partum. Penelitian Miyansaski, Misrawati, \& Sabrian (2014) menemukan bahwa $32,1 \%$ dari ibu dengan persalinan normal mengalami kejadian post partum blues sedangkan pada ibu yang bersalin dengan sectio caesaria sebesar $35,7 \%$. Hal ini menunjukkan bahwa ibu yang bersalin dengan sectio caesaria memiliki kecenderungan mengalami kejadian post partum blues dibandingkan dengan yang menjalani persalinan normal.

Kejadian post partum blues pada ibu nifas merupakan prediktor terhadap kemungkinan terjadinya depresi post partum pada beberapa bulan setelah melahirkan. Hal ini memungkinkan bagi para tenaga kesehatan khususnya perawat dan bidan bersama dengan ibu dan keluarga untuk mendiskusikan alternatif tindakan untuk mencegah terjadinya depresi post partum. Perawat perlu lebih 
ekstra dalam mengidentifikasi kejadian post partum blues pada ibu dengan persalinan sectio caesaria dibandingkan dengan ibu dengan persalinan normal. Meskipun demikian tidak berarti bahwa perawat dan bidan tidak melakukan pengkajian post partum blues pada ibu yang melahirkan melalui persalinan normal.

\section{Hubungan paritas dengan kejadian post partum blues}

Hasil penelitian ini menunjukkan bahwa paritas ibu memiliki hubungan yang signifikan dengan kejadian post partum blues. Ibu yang memiliki paritas lebih dari satu (multipara) memiliki kecenderungan untuk mengalami post partum blues $(46,2 \%)$ dibandingkan dengan ibu yang paritas pertama (primipara) $(7,1 \%)$. Penelitian Fatmawati (2015) menunjukkan kejadian post partum blues pada multipara sebesar $32 \%$.

Penelitian ini berbeda dengan hasil yang ditemukan oleh Irawati \& Yuliani (2014) yang mencatatkan kejadian post partum blues pada primipara $(63,6 \%)$ lebih tinggi dari kejadian post partum blues pada multipara $(36,4 \%)$. Tidak dapat dipungkiri bahwa peningkatan hormon akan memperberat kecemasan serta terjadinya kekhawatiran terhadap peran baru dialami oleh ibu primigravida. Hal tersebut dapat memicu krisis yang dapat memicu kejadian post partum blues. Namun demikian, kejadian post partum blues yang disebabkan oleh multifaktorial serta berbagai intervensi yang telah dilakukan oleh ibu untuk mengurangi stres menjelang persalinan dapat menyebabkan hasil dari penelitian berbeda.

Salah satu faktor yang memicu terjadinya post partum blues pada ibu multipara adalah faktor fisik. Kelelahan fisik seringkali terjadi pada ibu akibat dari mengasuh anak hampir sepanjang waktu mulai dari memandikan bayi, mengganti popok, menyusui, stres pada saat anak rewel dan mengalami sakit, menidurkan anak dan berbagai aktivitas lainnya sangatlah menguras tenaga. Dengan kelahiran anak yang kedua atau yang ketiga, maka beban itu tentunya akan makin bertambah dan hal ini akan menimbulkan stres yang tinggi pada ibu. Hasil penelitian Fitriana \& Nurbaeti (2015) menunjukkan bahwa kejadian post partum blues lebih banyak terjadi pada multipara dibandingkan dengan primipara dengan rasio perbandingan 1,67 : 1 . Kejadian post partum blues pada ibu dengan multipara lebih banyak baik pada kondisi post partum blues ringan, sedang, maupun berat (Fitriana \& Nurbaeti, 2015).

\section{Hubungan dukungan keluarga dengan kejadian Post Partum Blues}

Hasil penelitian ini menunjukkan bahwa ibu melahirkan yang mendapat dukungan dari suami dan keluarga, sebagian besar $(74,1 \%)$ tidak mengalami postpartum blues, dan sisanya $25,9 \%$ mengalami post partum blues. Hal ini menunjukkan bahwa dukungan suami dan keluarga penting lainnya sangat penting dalam mencegah terjadinya post partum blues pada ibu melahirkan. Hal ini sejalan dengan penelitian yang dilakukan oleh Kurniasari \& Astuti (2015) menemukan bahwa ibu bersalin yang mendapat dukungan dari suami sebesar $62,9 \%$ ) dan hasil penelitian Fatimah (2009) dan Kurniasari \& Astuti (2015) yang menyatakan bahwa ada hubungan antara dukungan suami dengan kejadian postpartum blues pada ibu primigravida.

Dukungan suami dan keluarga penting lainnya sangat dibutuhkan oleh seorang ibu bersalin untuk mengurangi stresnya. Suami menjadi tempat bagi ibu dalam berbagi peran dan mencurahkan perasaannya serta menjadi teman dalam berkomunikasi yang dapat mengurangi beban bagi ibu. Kehadiran suami yang mendampingi ibu selama menjalani persalinan dan perawatan anggota keluarga yang baru hadir di tengah-tengah mereka sangat penting. Kelahiran anggota keluarga baru seringkali membuat fokus perhatian beralih dari ibu ke bayi sehingga seringkali ibu merasa terabaikan dan kurang mendapatkan perhatian. Kemampuan suami dalam membagi perhatian ke ibu dan bayi sangat penting dalam mencegah terjadinya kejadian post partum blues pada ibu nifas.

Selain suami, kehadiran anggota keluarga yang penting juga sangat dibutuhkan. Anggota keluarga yang penting bagi ibu antara lain orang tua, saudara kandung, mertua, tentunya sangat berarti bagi ibu yang baru melahirkan. Kehadiran mereka akan membantu ibu dalam menghadapi berbagai perubahan yang terjadi pada tubuhnya baik fisik, psikologis, maupun kehadiran anggota keluarga baru yang memerlukan proses adaptasi dan penyesuaian. Dukungan keluarga lain yang penting memberikan hiburan, pertukaran informasi dan pengalaman dalam merawat anak serta memberikan pengetahuan yang berharga bagi ibu dalam menghadapi perubahan dalam kehidupannya.

Ibu sebenarnya dapat melalui fase kehamilan dan persalinan yang penuh dengan perubahan yang begitu kompleks dan perubahan emosi yang meningkat, dengan aman, nyaman, dan bahagia. Suami sebagai pasangan yang bertanggung jawab dan orang penting lainnya dalam keluarga perlu hadir untuk mendampingi ibu dan membantu memberikan rasa aman, penghargaan dan dukungan, perawatan, cinta, dan kasih sayang yang merupakan hal penting dibutuhkan oleh ibu selama di rumah sakit dan bulan-bulan setelah melahirkan.Pembahasan berisi diskusi yang menghubungkan dan membandingkan hasil penelitian dengan teori/konsep/temuan dari hasil penelitian lain baik yang sejalan maupun tidak sejalan dengan hasil penelitian. Pembahasan tidak 
sekedar menarasikan hasil (tabel dan gambar), serta sebaiknya mengemukakan dampak dari hasil penelitian.

\section{KESIMPULAN}

Dari penelitian yang telah dilaksanakan dapat disimpulkan bahwa dda hubungan yang signifikan antara jenis persalinan dengan kejadian postpartum blues pada ibu nifas. lbu yang melahirkan dengan metode Sectio caesaria, memiliki kemungkinan untuk mengalami post partum blues dibandingkan dengan ibu yang melahirkan melalui persalinan pervaginam/normal. Ada hubungan yang signifikan antara paritas ibu dengan kejadian postpartum blues pada ibu nifas. Ibu yang multipara memiliki kemungkinan untuk mengalami kejadian post partum blues lebih tinggi dibandingkan dengan ibu primipara. Dukungan suami dan keluarga sangat penting dalam mencegah terjadinya postpartum blues pada ibu nifas.

\section{SARAN}

Perawat dan Bidan harus melakukan skrining pada ibu post partum untuk mendeteksi kejadian postpartum blues sehingga dapat diambil tindakan untuk mencegah keberlanjutannya menjadi depresi post partum. Suami dan anggota keluarga yang penting lainnya harus hadir dan mendampingi ibu selama proses kehamilan dan melahirkan untuk mengurangi tingkat stres ibu dan mencegah terjadinya post partum blues. Dokter perlu mempertimbangkan risiko kejadian postpartum blues sebelum menetapkan tindakan operasi sectio caesaria pada ibu yang akan menjalani persalinan. Perawat dan Bidan perlu mempersiapkan dengan baik ibu yang menjalani persalinan dengan metode sectio caesaria terutama untuk menurunkan stres selama persiapan operasi, pelaksanaan, dan post operasi serta mendampingi ibu untuk mengurangi stresnya termasuk persiapan pulang dan perawatan luka yang baik.

\section{UCAPAN TERIMA KASIH}

Ucapan terima kasih penulis sampaikan kepada Ketua STIKES Nani Hasanuddin Makassar yang telah memberikan dukungan dalam penelitian ini serta kepada Ketua Yayasan Pendidikan Nani Hasanuddin Makassar yang telah bersedia membiayai penelitian ini sampai selesai. Ucapan terima kasih juga kami sampaikan kepada Direktur RS. Bhayangkara Makassar yang telah memberikan ijin melaksanakan penelitian serta kepada Kepala Perawatan Nuri beserta staf di ruang perawatan yang telah bersedia membantu dan ucapan terima kasih yang sebesar-besarnya penulis sampaikan kepada seluruh ibu nifas yang telah bersedia berpartisipasi dalam penelitian ini.

\section{DAFTAR PUSTAKA}

Arfian, S. 2012. Baby blues. Solo: Metagraf.

Bobak. 2005. Buku ajar keperawatan maternitas (edisi 4). Jakarta : EGC.

Fatimah, S. 2009. Hubungan dukungan suami dengan kejadian post partum blues pada ibu primipara di Ruang Bugenvile RSUD Tugurejo Semarang, http://eprints.undip.ac.id/10729/1/ARTIKEL.pdf

Fatmah, I., Rahma., Ikhsan, M. 2012. Faktor-faktor yang berhubungan dengan depresi postpartum di RSIA Pertiwi Makassar Tahun 2012, http://repository.unhas.ac.id/handle/ 123456789/4250

Fatmawati, D.A. 2015. Faktor risiko yang berpengaruh terhadap kejadian postpartum blues. Jurnal Edu Health. Vol. 5 No. 2. https://www.journal.unipdu.ac.id/ index.php/eduhealth/article/download/475/422

Fitriana, L.A.Nurbaeti, S. 2015. Gambaran kejadian postpartum blues pada lbu Nifas berdasarkan karakterstik di $\begin{array}{llllll}\text { Rumah Sakit } \quad \text { Umum } & \text { Tingkat IV } & \text { Sariningsih } & \text { Kota } \\ \text { Bandung.htps://ejournal.upi.edu/index.php/JPKI//article/view/2479/1688 } & & \end{array}$

Freudenthal, Corst. M, \& Kaminski, M. 1999. Severe post-delivery blues: associated factors. Am J Health, (2); 37-44

Irawati, D., Yuliani, F. 2014. Pengaruh faktor psikososial dan cara persalinan terhadap terjadinya post partum blues pada ibu nifas (studi di ruang nifas RSUD R.A Bosoeni Mojokerto). Hospital Majapahit, Vol. 6, No. 1. http://www.academia.edu/download/45395692/ acuan_KTI.pdf

Kurniasari, D., Astuti, Y.A. 2015. Hubungan antara karakteristik ibu, kondisi bayi, dan dukungan sosial suami dengan 
post partum blues pada ibu dengan persalinan SC di Rumah Sakit Umum Ahmad Yani Metro Tahun 2014. Jurnal Kesehatan Holistik. Vol. 9, No. 3. Hal. 115-125.

Menacker and Dentzer, 2006. Alert and Responses: NIH Cesarean Conference Interpreting Meeting and Media Reports, (Online), (http://www.childbirthconnection.org

Miyansaski, A.U.,Misrawati.,Sabrian, F. 2014. Perbandingan kejadian post partum blues pada ibu post partum dengan persalinan normal dan sectio caesaria. JOM PSIK. Vol. 1, No. 2. https://media.neliti.com/media/publications/188786-ID-perbandingan-kejadian-post-partum-blues.pdf

Murtiningsih, Afin. 2012. Mengenal Baby Blues dan Pencegahannya. Jakarta: Niaga Swadaya.

Ratna. 2009. Perawatan pasca melahirkan. available online http://www.ratnarespati.com.

Sujiyatini. 2010. Asuhan Ibu Nifas Askeb III. Cyrillius Publisher. Jakarta. 